\title{
DUKUNGAN TEMAN SEBAYA DAN PENGARUHNYA TERHADAP KEDISIPLINAN SISWA
}

\author{
PEER SUPPORT AND THE INFLUENCE TO STUDENT DISCIPLINE
}

Oleh:

Ihsan $\mathrm{Mz}^{1}$

Isnaeni Marhani ${ }^{2}$

\begin{abstract}
Submitted:

02 April 2020

Revision:

12 Mei 2020

Accepted:

31 Mei 2020

This study aims to determine the effect of peer support to discipline on students of Madrasah " $X$ " Yogyakarta. The research subjects were students of the Madrasah " $X$ " Yogyakarta, which numbered 208 people. The measuring instrument used is the scale of peer support and disciplinary scale in the form of a Likert scale with four alternative answers. Data analysis used one predictor regression analysis technique. Based on data analysis, it was obtained that Ho was accepted and Ha was rejected, which means that partially the Peer Support variable $(X)$ did not significantly influence to Discipline $(Y)$. This is evident from the value $b 1=0.034$ with $t$ $=0.584$ and Sig. $=0.560$. Because of the value of Sig. > 0.05 (0.560>0.05), then Ho is accepted and Ha is rejected.
\end{abstract}

Keywords: Discipline; Peer; Support; Student

\begin{abstract}
ABSTRAK
Penelitian ini bertujuan untuk mengetahui pengaruh dukungan teman sebaya terhadap kedisiplinan pada siswa Madrasah " $X$ " Kota Yogyakarta. Subjek penelitian adalah siswa Madrasah " $X$ " Kota Yogyakarta yang berjumlah 208 orang. Alat ukur yang digunakan adalah skala dukungan teman sebaya dan skala kedisiplinan dalam bentuk skala Likert dengan alternatif empat jawaban. Analisis data menggunakan teknik analisis regresi satu prediktor. Berdasarkan analisis data, diperoleh bahwa Ho diterima dan Ha ditolak yang artinya secara parsial variabel Dukungan Teman Sebaya (X) tidak berpengaruh secara signifikan terhadap Kedisiplinan (Y). Hal ini dibuktikan melalui nilai b1 $=0,034$ dengan $\mathrm{t}=0,584$ dan Sig. $=0,560$. Oleh karena nilai Sig. $>0,05(0,560>0,05)$, maka Ho diterima dan Ha ditolak.
\end{abstract}

Kata kunci: Dukungan; Kedisiplinan; Siswa; Teman Sebaya

\section{PENDAHULUAN}

Sekolah adalah tempat siswa belajar secara mandiri, formal, serta lembaga atau tempat yang didesain untuk melaksanakan proses pembelajaran siswa yang dibimbing oleh guru. Sekolah terdiri dari beberapa jenjang, yaitu Sekolah Dasar (SD) atau Madrasah Ibtidaiyah (MI) sederajat, Sekolah Menengah Pertama (SMP) atau Madrasah Tsanawiyah (MTs)

\footnotetext{
${ }^{1}$ Ihsan Mz, Institut Agama Islam Negeri Palangka Raya, ihsan.mz@iain-palangkaraya.ac.id

2 Isnaeni Marhani, Universitas Muhammadiyah Palangka Raya, isnaeni.marhani@umpalangkaraya.ac.id
} 
sederajat, Sekolah Menengah Atas (SMA) atau Madrasah Aliyah (MA) sederajat, dan Perguruan Tinggi. Salah satu bagian penting yang harus ditanamkan dan dibiasakan pada sebuah lembaga pendidikan adalah kedisiplinan. Tujuan dari disiplin sekolah adalah untuk menciptakan keamanan, kenyamanan bagi siswa serta kelancaran kegiatan pembelajaran di sekolah. Tentu tidak hanya bagi siswa, namun seluruh warga sekolah diharapkan mampu menerapkan perilaku disiplin tersebut. Upaya membimbing kedisiplinan siswa merupakan tanggung jawab seluruh elemen sekolah. Namun seringkali image hukuman kedisiplinan ini tidak konstruktif (membangun kepribadian siswa) dan tidak edukatif (mendidik jiwa), yang seharusnya dapat dilakukan dengan cara yang lebih humanis dan edukatif sehingga dapat membentuk perilaku baik pada siswa (Najmudin dkk., 2019).

Salah satu aspek yang sangat penting dalam kehidupan adalah kemampuan seseorang untuk menerapkan kedisiplinan. Melalui kedisiplinan, seorang individu dapat berperilaku sesuai dengan yang seharusnya dan dapat pula mengaktualisasikan dirinya dengan baik. Sekolah adalah salah satu tempat yang dapat membentuk perilaku disiplin bagi muridmuridnya termasuk warga sekolah lainnya (Muhammad, 2019).

Prijodarminto (Ariananda dkk., 2014) mengemukakan bahwa perilaku disiplin tercipta melalui serangkaian proses dan perilaku yang menunjukkan nilai-nilai ketaatan pada Tuhan, ketertiban, dan keteraturan dalam mencari dan mendapatkan ilmu. Karena itu perilaku disiplin dalam pengertian ini menggambarkan keadaan yang terbentuk karena proses kepatuhan dan ketaatan yang dilakukan murid dalam memperoleh ilmu yang diinginkan. Lebih lanjut, disiplin merupakan kesadaran untuk melakukan segala sesuatu dengan teratur dan tertib sesuai dengan aturan-aturan yang berlaku dengan penuh tanggung jawab tanpa paksaan dari pihak manapun.

Disiplin dalam bahasa Inggris disebut "discipline" yang memiliki arti kepatuhan atau tata tertib. Kata disiplin dalam Bahasa Indonesia seringkali memiliki keterkaitan dengan tata tertib dan ketertiban. Istilah ketertiban memiliki makna kepatuhan seseorang dalam mengikuti peraturan karena dimotivasi oleh sesuatu yang datang dari luar dirinya (Prijodarminto, 1994). Sementara Elly (Hasbahuddin \& Rosmawati, 2019), mengatakan disiplin diartikan sebagai ketaatan dan kepatuhan yang muncul karena adanya kesadaran dan motivasi dari dalam diri sendiri.

Kedisiplinan sangat penting dan harus dimiliki siswa atau murid di sekolah. Disiplin akan membantu siswa dalam pembentukan perilaku, sikap dan mengantarkan siswa menuju kesuksesan, baik dalam belajar maupun ketika akan memasuki dunia kerja. Fungsi kedisiplinan menurut Tu'u (2004) antara lain: menata kehidupan bersama, menyadarkan seseorang bahwa dia perlu menghargai dengan cara taat dan patuh terhadap aturan yang berlaku, sehingga dirinya tidak merugikan pihak lain dan akan mewujudkan hubungan yang baik dengan sesama.

Biasanya, kepribadian seseorang dipengaruhi oleh lingkungan. Disiplin yang diberlakukan dalam lingkungan sekolah memberi dampak bagi perkembangan kepribadian yang baik. Oleh karenanya, dengan sikap disiplin seseorang akan terbiasa mengikuti dan patuh terhadap peraturan yang berlaku. Melatih kepribadian, perilaku, sikap, dan pola kehidupan yang baik dan berdisiplin tidak lahir dalam waktu singkat. Kedisiplinan hanya bisa terwujud jika seseorang punya niat yang sungguh-sungguh serta membiasakan diri dengan perilaku displin, dimana hal ini membutuhkan proses yang panjang. Salah satu proses untuk membentuk pribadi yang disiplin adalah melalui latihan. Disiplin dapat terwujud melalui 
motivasi dari diri sendiri, dan bisa pula terjadi karena adanya paksaan dan tekanan dari luar. Dalam perkembangannya, perilaku disiplin terbadi menjadi tiga tahap, yaitu preconventional, conventional dan tahap Postconventional (Yasin, 2011).

Pada lembaga pendidikan, diantara faktor yang memengaruhi kepribadian siswa adalah teman sebaya. Santrock (2018) berpendapat bahwa teman sebaya (peers) adalah anak-anak atau remaja yang memiliki umur atau tingkat kematangan yang kurang lebih sama. Hurlock (1981) menyatakan bahwa dukungan sosial dari rekan sebaya terlihat dari perasaan senasib yang kemudian melahirkan hubungan saling mengerti dan memahami masalah masingmasing, saling memberi simpati, saling menasehati yang boleh jadi tidak didapatkan dari orangtuanya pada waktu yang bersamaan. Adapun Erikson (Ariananda dkk., 2014) mengungkapkan bahwa remaja memperoleh dukungan sosial dari kelompok teman seusianya. Oleh karena itu, remaja berusaha menggabungkan diri dengan kawan-kawan yang sebaya dengannya. Purnama (Ristianti, t.t.) membenarkan hal itu dengan menyatakan bahwa pada fase ini, remaja akan menghadapi beragam masalah yang tidak bisa mereka selesaikan sendiri tanpa adanya dukungan dan bimbingan dari orang-orang terdekatnya, dalam hal ini teman seusianya. Johnson (Ristianti, t.t.) mengemukakan bahwa dukungan sosial dapat berasal dari significant others (individu-individu penting) yang dekat dengan individu yang memerlukan bantuan.

Dukungan teman sebaya dapat dirasakan dengan melihat beberapa aspek. House (Smet, 1994) mengelompokkan ada empat aspek dukungan yang bisa diberikan oleh teman sebaya, yaitu: 1) Dukungan emosional, yaitu bantuan dalam bentuk pemberian kasih sayang dan kehangatan, kepedulian, perhatian, memberikan kepercayaan terhadap individu serta mengungkapkan rasa simpati dan empati kepada sesama. 2) Dukungan penghargaan, bisa melalui penghargaan atau penilaian yang positif terhadap individu, motivasi untuk maju dan semangat atau persetujuan tentang pendapat, ide atau gagasan orang lain serta melakukan perbandingan secara positif terhadap individu lain. 3) Dukungan informasi, yaitu pemberian informasi, saran, nasehat, ataupun feed back tentang apa yang seharusnya dilakukan oleh individu lain yang memerlukan. 4) Dukungan instrumental, yang meliputi bantuan langsung seperti memberikan pinjaman uang atau menolong dalam bentuk pekerjaan dalam rangka menyelesaikan tugas-tugas individu.

Egbert \& Wright (2019) mengungkapkan bahwa ada beberapa faktor yang mempengaruhi efektifitas dukungan teman sebaya, yaitu pertama, Pemberian dukungan. Dalam hal ini, pemberian dukungan yang dimaksud adalah sosok yang memiliki arti penting dalam kehidupan individu tersebut. Dapat berasal dari orang tua, keluarga lain, sahabat, tokoh masyarakat, dan sebagainya. Kedua, jenis dukungan. Segala bentuk dukungan yang diterima oleh individu akan memiliki arti bila dukungan itu bermanfaat dan sesuai dengan situasi yang ada. Ketiga, penerimaan dukungan. Kebiasaan, kepribadian, dan peran sosial merupakan karakteristik penerimaan dukungan yang akan menentukan keefektifan dukungan. Keempat, permasalahan yang dihadapi. Dukungan sosial yang tepat sangat tergantung oleh kecocokan antara jenis dukungan yang diberikan dengan masalah yang menimpa. Kelima, waktu pemberian dukungan. Dukungan sosial akan optimal saat berada dalam situasi dan waktu yang tepat. Keenam, durasi pemberian dukungan. Durasi pemberian dukungan tergantung pada kemampuan pemberi dukungan. Jika yang memberi dukungan mampu bertahan lama dan secara konsisten dapat melakukan kerja tersebut, maka semakin lama pula individu yang mendapatkan masalah bisa terbantu.

Terdapat beberapa riset yang telah dilakukan dan menjadikan dukungan teman sebaya sebagai salah satu variabel. Wahyuni (2016) meneliti tentang hubungan antara dukungan 
sosial teman sebaya dengan kemampuan bersosialisasi, yang hasilnya terdapat hubungan antara dua variabel tersebut. Lutfi (2012) meneliti tentang hubungan antara dukungan teman sebaya dengan kemampuan pemecahan masalah yang melahirkan kesimpulan bahwa terdapat hubungan positif yang sangat signifikan antara dukungan teman sebaya dengan kemampuan pemecahan masalah. Adapun Sinaga \& Kustanti (2017) melakukan penelitian tentang hubungan antara dukungan sosial teman sebaya dengan efikasi diri wirausaha yang menggunakan teknik pengambilan sampel cluster random sampling. Hasil penelitian ini menunjukan adanya hubungan positif yang signifikan antara dukungan sosial teman sebaya dengan efikasi diri wirausaha.

Seluruh penelitian yang telah dipaparkan di atas menunjukkan adanya hubungan positif dukungan teman sebaya (X) terhadap variabel yang diteliti (Y). Temuan ini sejalan dengan teori yang telah diungkap Erikson (Ristianti, t.t.) bahwa remaja menerima dukungan sosial dari kelompok teman sebaya. Oleh karena itu, remaja berusaha menggabungkan diri dengan teman-teman yang seusia dengan mereka. Perasaan senasib menjadi salah satu alasan remaja merasa nyaman dengan teman sebayanya karena saling memahami, menasehati, bahkan memberi yang kadang-kadang tidak mereka dapatkan dari orangtua (Santrock, 2006).

Pada aspek kedisiplinan, sejumlah penelitian dengan subjek yang berbeda-beda telah banyak dilakukan. Wicaksono (2014) meneliti tentang pengaruh dukungan sosial dan pola asuh otoriter orangtua yang memiliki latar belakang militer dan non-militer terhadap kedisiplinan siswa. Kesimpulan penelitian ini menunjukkan adanya pengaruh yang signifikan. Saputra dkk. (2014) melakukan penelitian tentang pengaruh konsep diri siswa dan penegakan peraturan terhadap tingkat kedisiplinan siswa. Penelitian ini menunjukkan hasil yang positif yaitu ada pengaruh konsep diri dan penegakan aturan terhadap kedisiplinan. Haryuni (2013) dalam penelitiannya mengungkap sebuah temuan yang menunjukkan adanya peranan bimbingan konseling pendidikan dalam membentuk kedisiplinan. Hasil penelitian Haryuni sejalan dengan teori dasar tentang pendekatan konseling direktif yang mengasumsikan bahwa manusia merupakan makhluk rasional dan memiliki potensi yang bisa dikembangkan ke arah positif (Ngalimun \& Mz, 2020). Kurniawati dkk. (2015) meneliti pengaruh pemberian sanksi terhadap kedisiplinan siswa dan menyimpulkan bahwa pemberian sanksi terhadap siswa berhasil meningkatkan kedisiplinan.

Perbedaan yang terdapat dalam penelitian ini dengan penelitian-penelitian yang telah diurai di atas adalah latar belakang penelitian ini dilakukan karena adanya kecenderungan bahwa aspek kedisiplinan dalam sistem pendidikan menghadapi dilema, yaitu rendahnya kesadaran dalam berperilaku disiplin. Pada waktu yang bersamaan, disiplin terhadap tata tertib sekolah hanya didasarkan pada paksaan (Dreikurs \& Cassel, 1986). Akibatnya, siswa tidak menyadari bahwa disiplin dalam mematuhi dan mentaati aturan merupakan tanggung jawab siswa dan tentunya akan memberikan manfaat yang nyata bagi diri mereka. Kohlberg (Widodo, 2013) menambahkan bahwa sikap disiplin akan lebih mudah tumbuh bila muncul dari kesadaran dalam diri seseorang, bukan dengan paksaan. Tujuan penelitian ini adalah untuk melihat seberapa besar pengaruh dukungan teman sebaya terhadap kedisiplinan siswa Madrasah "X" di Kota Yogyakarta.

\section{METODE}

Penelitian ini mengkaji dua variabel, yaitu dukungan teman sebaya sebagai variabel bebas, dan kedisiplinan sebagai variabel terikat. Serta satu variabel hubungan yakni: 
Pengaruh dukungan teman sebaya terhadap kedisiplinan. Dukungan teman sebaya, dalam penelitian ini adalah pola hubungan dengan teman sebaya. Di antara indikator yang dilihat adalah penerimaan individu di dalam kelompoknya; pernyataan bahwa individu tersebut diabaikan oleh kelompoknya; atau pernyataan bahwa dia ditolak oleh kelompoknya.

Adapun variabel Kedisiplinan yaitu sifat sekaligus sikap yang berfungsi untuk membentuk kebiasaan positif dalam diri setiap siswa. Maka aspek disiplin yang diteliti adalah pemahaman yang baik mengenai sistem perilaku, sikap mental, bertanggung jawab, sikap kesungguhan hati, mampu mengendalikan diri dan konsisten. Aspek-aspek yang diambil yaitu ketaatan atau kepatuhan terhadap aturan, kesadaran untuk melaksanakan tugas sesuai dengan pedoman, tanggung jawab dan kejujuran.

Populasi pada penelitian ini adalah siswa Madrasah " $\mathrm{X}$ " yang berjumlah 6 kelas, dengan jumlah keseluruhan 208 siswa. Adapun teknik sampling dalam penelitian ini menggunakan Cluster Random Sampling. Peneliti menentukan subjek penelitian berasal dari seluruh siswa kelas X, sementara kelas try out berasal dari kelas XI yang berjumlah 50 orang siswa. Pertimbangan dalam menentukan subjek penelitian karena observasi awal menunjukkan bahwa kelas $\mathrm{X}$ memiliki tingkat kedisiplinan yang sedang. Adapun jumlah siswa Madrasah "X” Yogyakarta sebagai berikut:

Tabel 1. Jumlah Siswa Kelas X

\begin{tabular}{ll}
\hline \multicolumn{1}{r}{ KELAS } & Laki-laki \\
\hline X A & 41 \\
X B & 35 \\
X C & 35 \\
X D & 29 \\
X E & 33 \\
X F & 35 \\
\hline JUMLAH & 208 \\
\hline
\end{tabular}

Metode pemerolehan data menggunakan skala. Adapun skala yang peneliti gunakan adalah skala perilaku disiplin yang disusun berdasarkan aspek ketaatan atau kepatuhan terhadap aturan, kesadaran untuk melaksanakan tugas sesuai dengan pedoman, tanggung jawab, dan kejujuran. Berikutnya skala dukungan teman sebaya yang disusun berdasarkan aspek dukungan emosional, dukungan penghargaan, dukungan instrumental, dan dukungan informasi. Keduanya adalah skala tertutup, yaitu skala (kuesioner) yang disusun dengan menyediakan pilihan jawaban lengkap sehingga subjek tinggal memberi tanda pada jawaban yang dipilih (sesuai).

Model skala yang digunakan adalah Skala Likert, dengan alternatif empat jawaban (SS) sangat sesuai, (S) sesuai, (TS) tidak sesuai, (STS) sangat tidak sesuai. Pada item Favorable jawaban sangat sesuai (SS) diberi skor 4, sesuai (S) diberi skor 3, (TS) tidak sesuai diberi skor 2, (STS) sangat tidak sesuai diberi skor 1. Sementara pada jawaban Unfavorable sangat sesuai (SS) diberi skor 1, sesuai (S) diberi skor 2, (TS) tidak sesuai diberi skor 3, dan (STS) sangat tidak sesuai diberi skor 4. Semakin rendah skor yang diperoleh mengindikasikan rendahnya perilaku disiplin dan dukungan teman sebaya pada subyek yang diteliti. Sebaliknya semakin tinggi skor yang diperoleh dari subyek mengindikasikan tingginya perilaku disiplin dan dukungan teman sebaya. 


\section{HASIL DAN PEMBAHASAN}

Penelitian ini akan mengurai hasil analisis deskriptif yang menggunakan software SPSS 21 for Windows yang dipandu melalui buku tulisan Ghozali (2006). Sumber teori pendukung yang lain diambil dari buku Arikunto (2014) dan Nasehudin \& Gozali (2012). Hasil analisis tersebut menunjukkan skor Minimum, skor Maksimum, Mean, dan Standar Deviasi dari masing-masing variabel. Tabel di bawah ini merupakan hasil penghitungan komputasi, sebagai berikut:

Tabel 2.

Hasil Deskripsi Statistik

\begin{tabular}{|c|c|c|c|c|c|}
\hline & $\mathrm{N}$ & Minimum & Maksimum & Mean & Std. Deviation \\
\hline Teman Sebaya & 195 & 44.00 & 120.00 & 95.2000 & 11.76952 \\
\hline Kedisiplinan & 195 & 66.00 & 124.00 & 95.3641 & 10.79116 \\
\hline $\begin{array}{l}\text { Valid } \\
\text { (listwise) }\end{array}$ & 195 & & & & \\
\hline
\end{tabular}

Uji normalitas bertujuan untuk menguji apakah dalam model regresi, variabel bebas (Dukungan Teman Sebaya) dan variabel terikat (Kedisiplinan), keduanya terdistribusikan secara normal ataukah tidak normal. Pengujian normalitas dalam penelitian ini dilakukan dengan uji statistik One Sample Kolmogorof Smirnov Test. Jika nilai Asymp Sig lebih dari atau sama dengan 0,05, maka data terdistribusi secara normal. Sementara jika Asymp Sig kurang dari 0,05, maka data terdistribusi secara tidak normal. Berdasarkan analisis yang dilakukan, hasil analisanya adalah sebagai berikut:

Tabel 3.

Hasil Uji Normalitas

One-Sample Kolmogorov-Smirnov Test

\begin{tabular}{|c|c|c|c|}
\hline & & Teman Sebaya & Kedisiplinan \\
\hline $\mathrm{N}$ & & 195 & 195 \\
\hline \multirow[t]{2}{*}{ Normal Parameters ${ }^{a, b}$} & Mean & 95.20 & 95.36 \\
\hline & Std. Deviation & 11.770 & 10.791 \\
\hline \multirow[t]{3}{*}{ Most Extreme Differences } & Absolute & .086 & .058 \\
\hline & Positive & .044 & .058 \\
\hline & Negative & -.086 & -.035 \\
\hline Kolmogorov-Smirnov Z & & 1.197 & .814 \\
\hline Asymp. Sig. (2-tailed) & & .114 & .522 \\
\hline
\end{tabular}

a. Test distribution is Normal.

b. Calculated from data.

Berdasarkan hasil analisis di atas diperoleh data untuk variabel Dukungan Teman Sebaya sebesar 0,114, dan variabel Kedisiplinan sebesar 0,522. Oleh karena kedua variabel tersebut memiliki nilai Asymp Sig yang lebih besar dari 0,05, maka dapat disimpulkan bahwa data variabel-variabel tersebut berdistribusi secara normal. 
Uji linieritas bertujuan untuk mengetahui apakah dua variabel atau lebih mempunyai hubungan yang linier secara signifikan atau tidak. Uji ini digunakan sebagai prasyarat dalam analisis korelasi atau regresi linier, seperti pada penelitian ini. Pengujian pada SPSS dengan menggunakan Test for Linearity pada taraf signifikansi 0,05. Dua variabel dikatakan mempunyai hubungan yang linier apabila signifikansi (linearity) kurang dari 0,05. Berdasarkan analisis didapatkan hasil sebagai berikut:

Tabel 4.

Hasil Uji Linieritas Antara Kedisiplinan dengan Dukungan Teman Sebaya

\begin{tabular}{|c|c|c|c|c|c|c|c|}
\hline & & & $\begin{array}{l}\text { Sum of } \\
\text { Squares }\end{array}$ & $D f$ & $\begin{array}{l}\text { Mean } \\
\text { Square }\end{array}$ & $F$ & Sig. \\
\hline \multirow{5}{*}{$\begin{array}{l}\text { TemanSebaya } \\
* \text { Kedisiplinan }\end{array}$} & \multirow{3}{*}{$\begin{array}{l}\text { Between } \\
\text { Groups }\end{array}$} & (Combined) & 11575.194 & 47 & 246.281 & 2.367 & .000 \\
\hline & & Linearity & 6073.755 & 1 & 6073.755 & 58.363 & .000 \\
\hline & & $\begin{array}{l}\text { Deviation } \\
\text { from Linearity }\end{array}$ & 5501.439 & 46 & 119.596 & 1.149 & .265 \\
\hline & \multicolumn{2}{|c|}{ Within Groups } & 15298.006 & 147 & 104.068 & & \\
\hline & \multicolumn{2}{|l|}{ Total } & 26873.200 & 194 & & & \\
\hline
\end{tabular}

Berdasarkan Tabel 4 di atas, hasil analisis menunjukkan bahwa nilai $\mathrm{F}$ yang ditemukan adalah sebesar 58,363 dengan Sig. 0,000. Oleh karena nilai Sig tersebut kurang dari 0,05, maka dapat disimpulkan bahwa hubungan antara variabel Dukungan Teman Sebaya dengan Kedisiplinan bersifat linier.

Persamaan regresi linier yang diperoleh disajikan pada tabel di bawah ini:

Tabel 5.

Persamaan Regresi Linier

\begin{tabular}{|c|c|c|c|c|c|}
\hline \multicolumn{6}{|l|}{ Coefficients $^{a}$} \\
\hline \multirow{2}{*}{ Model } & \multicolumn{2}{|c|}{$\begin{array}{l}\text { Unstandardized } \\
\text { Coefficients }\end{array}$} & \multirow{2}{*}{$\begin{array}{l}\text { Standardized } \\
\text { Coefficients } \\
\text { Beta }\end{array}$} & & \multirow{2}{*}{ Sig. } \\
\hline & B & $\begin{array}{l}\text { Std. } \\
\text { Error }\end{array}$ & & & \\
\hline 1 (Constant) & 10.556 & 5.921 & & 1.783 & .076 \\
\hline $\begin{array}{l}\text { Dukungan } \\
\text { Sebaya }\end{array}$ & Teman .034 & .059 & .037 & .584 & .560 \\
\hline
\end{tabular}

a. Variabel Dependen (Terikat): Kedisiplinan

Pengujian hipotesis secara parsial menggunakan nilai t, yaitu untuk menguji secara parsial peran variabel bebas terhadap variabel terikat. Hasil perhitungan dijelaskan dengan tetap mengacu pada Tabel 5 di atas, yang dideskripsikan sebagai berikut, yaitu di mana (Ho) Tidak ada pengaruh positif Dukungan Teman Sebaya (X) terhadap Kedisiplinan (Y). (Ha) Ada pengaruh positif Dukungan Teman Sebaya (X) terhadap Kedisiplinan (Y). Uji terhadap variabel Dukungan Teman Sebaya $(\mathrm{X})$ ditemukan nilai $\mathrm{b} 1=0,034$ dengan $\mathrm{t}=$ 0,584 dan Sig. $=0,560$. Oleh karena nilai Sig. $>0,05(0,560>0,05)$, maka Ho diterima dan Ha ditolak. 
Munawarah dkk. (2019) ketika meneliti tentang hubungan antara dukungan teman sebaya terhadap regulasi diri pada remaja menunjukkan adanya pengaruh yang positif. Alasannya karena hubungan sosial yang baik akan menimbulkan regulasi yang baik juga. Ketika remaja memiliki regulasi diri yang tinggi akan melahirkan kemampuan untuk membuat perencanaan, dan motivasi untuk bertindak. Sementara Sovayunanto dkk. (2019) mengemukakan hasil yang positif antara dukungan sosial teman sebaya dengan prestasi belajar siswa.

Maryatun (2013) dalam penelitiannya tentang hubungan peran teman sebaya terhadap perilaku seksual pranikah remaja menemukan fakta bahwa terdapat hubungan yang positif antara teman sebaya dengan perilaku seksual pranikah. Penelitian ini dilakukan terhadap siswa sekolah menengah kota Surakarta. Hasil penelitian yang sama juga ditemukan dalam Novitasari (2014) yang meneliti tentang perilaku seks pranikah pada remaja di salah satu sekolah kota Samarinda. Usman (2013) mengurai tentang hubungan kepribadian, komunikasi, kelompok teman sebaya dan iklim sekolah terhadap perilaku bullying. Kesimpulan penelitian ini menginformasikan bahwa perilaku bullying dapat ditekan dengan adanya kepribadian baik yang tumbuh pada diri siswa, kemampuan komunikasi intrapersonal yang positif, iklim sekolah yang kondusif dan teman sebaya yang mendukung (peer support).

Suparno (2013) dalam penelitiannya mengungkap bahwa terdapat korelasi antara konformitas teman sebaya dengan konsep diri. Ekasari \& Yuliyana (2012) yang meneliti tentang koping stres menyimpulkan bahwa terdapat hubungan yang positif antara dukungan teman sebaya, kontrol diri dengan kemampuan koping stres pada siswa di salah satu sekolah kota Bogor. Hapasari \& Primastuti (2014) meneliti tentang kepercayaan diri mahasiswa Papua ditinjau dari dukungan teman sebaya yang menyimpulkan bahwa terdapat hubungan positif yang sangat signifikan antara dua variabel yang diteliti tersebut.

Penelitian-penelitian mutakhir banyak menyinggung tentang peranan dukungan teman sebaya terhadap masalah sosial termasuk kesehatan mental. Watts \& Higgins (2017) dalam bukunya yang berjudul "Narratives of Recovery from Mental Illness: The Role of Peer Support" menemukan bahwa penyakit mental dapat disembuhkan dengan menciptakan support system dalam bentuk dukungan teman sebaya. Watts mengungkap pengalaman 26 orang yang mengalami gangguan mental dan tergabung dalam sebuah kelompok yang diberi nama "Grow". Kelompok ini diberi treatment khusus yang dipandu oleh tenaga-tenaga profesional. Drebing (2016) menuturkan bahwa teman sebaya sangat berperan penting dalam menciptakan lingkungan sosial yang kondusif. Teori Drebing ini dapat diterapkan dalam berbagai setting lokasi. Watson \& Meddings (2019) mengungkap bahwa dukungan teman sebaya akan berhasil jika dilakukan dengan menerapkan strategi yang tepat serta menjalankan fungsi yang sesuai dengan konsep dan teori yang ada.

Hasil dari penelitian di atas, termasuk referensi-referensi dari Barat menunjukkan bahwa dukungan teman sebaya memiliki pengaruh yang signifikan dalam banyak hal. Penelitian ini memperlihatkan hasil yang berbeda sebab variabel yang diteliti tidak sama dengan variabel penelitian yang telah diurai di atas. Selain itu menurut Yasin (2011), sikap disiplin bukan merupakan sesuatu yang terjadi secara otomatis atau spontan pada diri seseorang melainkan kedisiplinan terbentuk atas dasar beberapa faktor yang mempengaruhinya. Secara umum ada dua faktor yang mempengaruhi kedisiplinan yaitu internal dan eksternal. Faktor internal yaitu: pembawaan diri, kesadaran diri, pengaruh pola pikir, minat dan motivasi. Sementara faktor eksternal dapat dipengaruhi oleh keteladanan, nasihat, latihan, lingkungan dan kelompok. Oleh karena itu dapat dikatakan bahwa dukungan 
teman sebaya hanya merupakan salah satu bagian dari faktor-faktor yang dapat mempengaruhi kedisiplinan. Faktor yang lain masih banyak sehingga untuk variabel dukungan teman sebaya - dalam penelitian ini — tidak memberikan pengaruh yang positif dan signifikan terhadap kedisiplinan. Selain itu, faktor tempat pengambilan data penelitian juga dapat memengaruhi hasil yang didapatkan. Melalui argumentasi tersebut maka secara parsial variabel Dukungan Teman Sebaya (X) tidak berpengaruh secara signifikan terhadap Kedisiplinan (Y).

\section{KESIMPULAN}

Berdasarkan hasil analisa data dan pembahasan dalam penelitian ini, maka dapat disimpulkan bahwa tidak ada peran positif Dukungan Teman Sebaya terhadap Kedisiplinan. Artinya Dukungan Teman Sebaya tidak memberikan pengaruh terhadap Kedisiplinan siswa. Setelah melihat kesimpulan di atas, maka peneliti mengajukan saran yang ditujukan kepada: Peneliti selanjutnya, agar menjadikan penelitian ini sebagai salah satu sumber informasi yang berfungsi sebagai pembanding atau pelengkap dari penelitian-penelitian yang akan datang. Kesimpulan dari penelitian ini menunjukkan bahwa tidak ada pengaruh positif dukungan teman sebaya dengan kedisiplinan siswa. Hasil ini tentu dapat dikaji lebih lanjut sekaligus dibandingkan dengan penelitian berikutnya. Penelitian ini jika dibandingkan dengan penelitian yang akan datang dapat dilihat dari berbagai perspektif, yaitu: subjek penelitian, lokasi, variabel yang digunakan, metode pengambilan data, alat ukur, metode analisis data serta faktor-faktor lain yang relevan. Adanya perbedaan perspektif tersebut berpotensi melahirkan kesimpulan yang juga berbeda.

\section{DAFTAR PUSTAKA}

Ariananda, E. S., Hasan, S., \& Rakhman, M. (2014). Pengaruh kedisiplinan siswa di sekolah terhadap prestasi belajar siswa teknik pendingin. Journal of Mechanical Engineering Education, 1(2), 233-238.

Arikunto, S. (2014). Prosedur penelitian: Suatu pendekatan praktik. Rineka Cipta.

Drebing, C. (2016). Leading peer support and self-help groups: A pocket resource for peer specialists and support group facilitators ( $1^{\text {st }} \mathrm{ed}$.). Morrisville, NC: Lulu Com.

Dreikurs, R., \& Cassel, P. (1986). Disiplin tanpa hukuman (Edisi keempat). Bandung: Remadja Karya.

Egbert, N., \& Wright, K. B. (2019). Social support and health in the digital age. Lanham, MD: Lexington Books.

Ekasari, A., \& Yuliyana, S. (2012). Kontrol diri dan dukungan teman sebaya dengan coping stress pada remaja. SOUL: Jurnal Pemikiran Dan Penelitian Psikologi, 5(2), 55-66.

Ghozali, I. (2006). Aplikasi analisis multivariate dengan program spss. Semarang: Badan Penerbit Universitas Diponegoro.

Hapasari, A., \& Primastuti, E. (2014). Kepercayaan diri mahasiswi papua ditinjau dari dukungan teman sebaya. PSIKODIMENSIA, 13(1), 60-72.

Haryuni, S. (2013). Penerapan bimbingan konseling pendidikan dalam membentuk kedisiplinan layanan bimbingan pengembangan diri. Edukasia: Jurnal Penelitian Pendidikan Islam, 8(2), 389-415.

Hasbahuddin, H., \& Rosmawati, R. (2019). Implementasi teknik pengelolaan diri untuk meningkatkan kedisiplinan siswa. KONSELING: Jurnal Ilmiah Penelitian Dan Penerapannya, 1(1), 11-18. 
Hurlock, E. B. (1981). Developmental psychology: A life-span approach (5 ${ }^{\text {th }}$ ed.). New Delhi: Tata McGraw-Hill.

Kurniawati, E., Zahirman, Z., \& Eddison, A. (2015). Analisis tingkat kedisiplinan siswa akibat pemberian sanksi material di sma negeri 1 bukit batu kabupaten bengkalis. Jurnal Online Mahasiswa (JOM) Bidang Keguruan Dan Ilmu Pendidikan, 2(2), 1-8.

Lutfi, D. N. (2012). Hubungan antara dukungan teman sebaya dengan kemampuan pemecahan masalah pada santriwati pengurus organisasi pelajar ppmi assalaam (op3mia) (Skripsi tidak diterbitkan). Universitas Muhammadiyah Surakarta, Surakarta.

Maryatun. (2013). Peran teman sebaya terhadap perilaku seksual pra nikah pada remaja di sma muhammadiyah 3 surakarta. Gaster, 10(1), 39-47.

Muhammad, A. F. N. (2019). Menumbuhkan kedisiplinan siswa melalui strategi manajemen intervensi. Jurnal Pemikiran Dan Pengembangan Sekolah Dasar (JP2SD), 7(1), 7-14.

Munawarah, M., Latipun, L., \& Amalia, S. (2019). Kontribusi dukungan teman sebaya terhadap regulasi diri pada remaja. PSIKOVIDYA, 23(2), 150-163.

Najmudin, N., Fauzi, F., \& Ikhwani, I. (2019). Program kedisiplinan siswa di lingkungan sekolah: Studi kasus di dayah terpadu (boarding school) sma babul maghfirah aceh besar. Edukasi Islami: Jurnal Pendidikan Islam, 8(02), 183-206.

Nasehudin, T. S., \& Gozali, N. (2012). Metode penelitian kuantitatif. Bandung: Pustaka Setia.

Ngalimun, N., \& Mz, I. (2020). Bimbingan konseling di sekolah dasar dan madrasah ibtidaiah (Edisi pertama). Yogyakarta: CV. Litera.

Novitasari. (2014). Pengaruh teman sebaya terhadap perilaku seks pranikah pada remaja di smkn 5 samarinda. MOTIVASI, 2(1), 142-146.

Prijodarminto, S. (1994). Disiplin: Kiat menuju sukses (edisi keempat). Jakarta: Pradnya Paramita.

Ristianti, A. (t.t.). Hubungan antara dukungan sosial teman sebaya dengan identitas diri pada remaja di sma pusaka 1 jakarta (Skripsi tidak diterbitkan). Universitas Gunadarma, Depok.

Santrock, J. W. (2006). Life-span development (10 ${ }^{\text {th }}$ ed.). New York, NY: McGraw-Hill.

Santrock, J. W. (2018). Adolescence (17 ${ }^{\text {th }}$ ed.). New York, NY: McGraw-Hill Education.

Saputra, E., Suntoro, I., \& Adha, M. M. (2014). Pengaruh penguasaan konsep diri dan penegakan peraturan terhadap tingkat kedisiplinan. Jurnal Kultur Demokrasi, 2(8), 114.

Sinaga, D. H., \& Kustanti, E. R. (2017). Hubungan antara dukungan sosial teman sebaya dengan efikasi diri wirausaha pada mahasiswa fakultas ilmu sosial dan ilmu politik universitas diponegoro. Empati, 6(1), 74-79.

Smet, B. (1994). Psikologi kesehatan. Jakarta: PT. Grasindo.

Sovayunanto, R., Pribadi, H., \& Arafah, Z. (2019). Hubungan dukungan sosial teman sebaya pada prestasi belajar siswa kelas xi di man tarakan. Jurnal Borneo Humaniora, 2(1), $38-42$.

Suparno, S. (2013). Konformitas teman sebaya, konsep diri dan kenakalan remaja. Persona: Jurnal Psikologi Indonesia, 1(2), 99-104.

Tu'u, T. (2004). Peran disiplin pada perilaku dan prestasi siswa. Jakarta: PT. Grasindo.

Usman, I. (2013). Kepribadian, komunikasi, kelompok teman sebaya, iklim sekolah dan perilaku bullying. HUMANITAS: Indonesian Psychological Journal, 10(1), 49-60.

Wahyuni, N. S. (2016). Hubungan dukungan sosial teman sebaya dengan kemampuan bersosialisasi pada siswa smk negeri 3 medan. JURNAL DIVERSITA, 2(2), 1-11.

Watson, E., \& Meddings, S. (2019). Peer support in mental health. London: Red Globe Press. 
Watts, M., \& Higgins, A. (2017). Narratives of recovery from mental illness: The role of peer support. London: Routledge, Taylor \& Francis Group.

Wicaksono, D. A. (2014). Kedisiplinan siswa ditinjau dari dukungan sosial dan pola asuh otoriter orang tua pada siswa yang berlatar belakang berbeda (tni dan non-tni). Widya Warta, 1(38), 132-141.

Widodo, B. (2013). Perilaku disiplin siswa ditinjau dari aspek pengendalian diri (self control) dan keterbukaan diri (self disclosure) pada siswa smk wonoasri caruban kabupaten madiun. Widya Warta, 37(01), 140-151.

Yasin, F. (2011). Penumbuhan kedisiplinan sebagai pembentukan karakter peserta didik di madrasah. Jurnal el-Hikmah, IX(1), 123-138. 